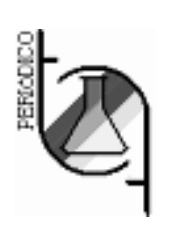

\title{
INFLUENCE OF THE VOLATILE FATTY ACID CONTENT TO RADIATION VULCANIZED NATURAL RUBBER LATEX (RVNRL)
}

\section{INFLUÊNCIA DO CONTEÚDO DE ÁCIDOS GRAXOS VOLÁTEIS NO LÁTEX DE BORRACHA NATURAL VULCANIZADO COM RADIAÇÃO IONIZANTE (RVNRL)}

\author{
CHIRINOS, Hugo David ${ }^{1}$;; CARVALHO DE JESUS, Sueli². \\ ${ }^{1}$ Universidad Nacional Micaela Bastidas de Apurimac - UNAMBA \\ Av. Arenas 121, Abancay/Apurimac - Perú. \\ ${ }^{2}$ Instituto de Pesquisas Energéticas e Nucleares - IPEN-CNEN/SP \\ Av. Lineu Prestes 2.242 \\ 05508-900 Butantã, São Paulo, SP, Brazil \\ ${ }^{*}$ Autor correspondente \\ *e-mail: hdccoll@hotmail.com
}

Received 07 April 2011; received in revised form 02 July 2011; accepted 28 October 2011

\section{RESUMO}

O látex de borracha natural é uma dispersão aquosa. Essas partículas estão estabilizadas na dispersão devido à formação de uma lâmina de proteína com carga elétrica. Qualquer condição que perturbe a formação da lâmina de proteína, afeta a estabilidade da dispersão. Pela adição de $1.2 \%$ em peso de $\mathrm{NH}_{3}$, a estabilidade da dispersão pode ser melhorada. O látex fresco foi irradiado mediante Co-60 com uma dose de irradiação de $10,20,30,40$ e $100 \mathrm{kGy}$. Os resultados mostraram uma relação entre o conteúdo de ácidos graxos voláteis (VFA, produto formado pelo ataque de micro-organismos no carboidrato) e a resistência natural ou propriedades físicas do filme vulcanizado. Baixos valores do VFA mostram uma alta resistência física do filme seja vulcanizado e não vulcanizado. Isto indica que a formação da estrutura tridimensional é responsável pelo bom rendimento das propriedades físicas do filme.

Palavras-chaves: RVNRL, vulcanização por radiação, ácidos graxos voláteis, borracha natural.

\begin{abstract}
Natural rubber latex is a dispersion of natural rubber particles in water. These particles are coated with a protein layer which will stabilize the dispersion in water by forming an electric charge in the layer. Any different condition affecting this layer disturbs the stability of dispersion. Microorganism attack disturbs the protein layer and consequently the stability of the dispersion. By adding $1.2 \%$ by weight of $\mathrm{NH}_{3}$, the stability of the dispersion can be improved. The fresh latex was irradiated by Co-60 with irradiation dose of 10, 20, 30, 40 and $100 \mathrm{kGy}$. The results showed a relationship between the volatile fatty acid content (VFA, product from microorganism attack on carbohydrate) and the green strength or the physical properties of vulcanized film. Low VFA number showing a higher physical strength of the film either un-vulcanized or vulcanized. It appeared that the structure was responsible in yielding a good physical property of the film.
\end{abstract}

Keywords: RVNRL, radiation vulcanization, volatile fatty acid, natural rubber. 


\section{INTRODUCTION}

The natural rubber (NR) latex concentrates used for the manufacture of dipped goods, such as gloves, are products both of nature and technology. They are made using the field latex obtained from the tree species "Hevea Brasiliensis" of the Euphorbiacea family. Nature provides the raw material, field latex, which is then modified, preserved, concentrated and tested by scientifically developed methods to produce the commercial concentrates.

The testing of concentrates is carried out immediately after preparation but certain properties, i.e. those liable to change, are retested at intervals up to the time of shipment. The properties liable to change are mechanical stability and the VFA volatile fatty acid content (product from microorganism attack on carbohydrate) and $\mathrm{KOH}$ numbers [1, 2].

NR latex is a dispersion of NR particles in water, and the diameter of the particles are between 0.2 and 1.0. Those particles are coated with a protein layer which will stabilize the dispersion in water by forming an electric charge in the layer [14]. Anything that disturbs this layer will disturb the stability of dispersion. Microorganism attack will disturb the protein layer and consequently the stability of the dispersion. By adding a $1.2 \%$ by weight of $\mathrm{NH}_{3}$, the stability of the dispersion can be improved.

To manufacture dipped goods practice shows that there was a clear relationship between the VFA content (VFA, product from microorganism attack on carbohydrate) and the green strength or the physical properties of vulcanized film.

The increasing level of automation, particularly in the dipping industry, and the need for high-volume output of guaranteed quality places increasing pressure on producers of latex to ensure uniformity of behavior of their product. Nonetheless, some variation does exist and this is most likely to be observed in the form of variable behavior on an automatic dipping machine. The elimination of this variability is a difficult task and it depends upon obtaining a much more detailed understanding of the factors that control the colloidal stability of the latex. The controlling, for example, the mechanical stability of the raw latex are not properly understood at present and the role of particle charge in determining stability is in doubt.

In this work investigations were carried out to find out well prepared concentrated NR latex will be able to form a good film of radiation vulcanized natural rubber latex, RVNRL. Although it is still in the development stage it has been shown $[3,4,5,6,9,10,12,13]$ that it can be used satisfactorily in coagulant dipping processes.

\section{MATERIALS AND METHODS}

Freshly preserved (ammonia solution) yield NR latexes was collected from established suppliers in the region of São José do Rio Preto. Yield latex used and its initial properties was as follow: Preserved in $0.8 \% \mathrm{NH}_{3}$ and $0.03 \% \mathrm{ZnO}$ and $0.03 \%$ Vulcatex; TSC: $36.6 \%$, DRC: $33.8 \%$; VFA: $0.026 \% ; \mathrm{pH}: 10.2$.

The testing (VFA and $\mathrm{KOH}$ ) of preserved latexes is carried out immediately after irradiation. The preserved yield latexes were irradiated under cobalt-60 source without stirring. The irradiation facility with $3 \mathrm{MCi}$ Cobalt-60 source is located at EMBRARAD - Brazil. The irradiation doses were $10,20,30$ and $40 \mathrm{kGy}$. The latex irradiated was stored for 1 month and 4 months and carried out the testing of VFA number.

The preparation of cast films $(0.2 \mathrm{~mm}$ thick) was done by spreading. $13 \mathrm{ml}$ of irradiated latex on each of the several raised rimmed glass plates. They were air dried (48 h) to transparent films, in a circulation oven at $50^{\circ} \mathrm{C}$ for $24 \mathrm{~h}$ after leaching. The leaching of the films was done with water at $70^{\circ} \mathrm{C}$. The period of leaching was about 20 minutes.

\subsection{Measurement of tensile strength at break} (Tb)

Dumbbell shaped test pieces were cut using standard dumbbell cutter ASTM D 1822-L [8] of precise size for natural rubber film. The thickness of the samples was measured using a micrometer. The average thickness was $0.23 \mathrm{~mm}$ with $4.0 \%$ deviations coefficient of the five samples used. Tensile strength at break and strain at break $(\mathrm{Eb})$ were measured with a tensile machine. All tests were done in room temperature.

\subsection{Measurement of volatile fatty acid number, VFA}


Volatile fatty acid number - the number of grams of potassium hydroxide $(\mathrm{KOH})$ required neutralizing the volatile fatty acid in a latex sample containing $100 \mathrm{~g}$ of total solids. The testing carried out according to standard ASTM D1076-79 [7] Modified Markham Semi-Micro Still apparatus was used. The serum was extracted of the lattices that will be analyzed. This serum is distilled, by dragged steam and then condensed. It is titrated with standard solution of $\mathrm{Ba}(\mathrm{OH})_{2}$. By the through result of titration, and the content of total solid and dry rubber, with this values can be calculate the volatile fatty acid number as Equation 1:

$V F A=(A \times N \times 561) /(W \times T S)$

Where: $A$ is a cubic centimeter of $\mathrm{Ba}(\mathrm{OH})_{2}$ solution required for titration of the sample; $\mathrm{N}$ is a normality of the $\mathrm{Ba}(\mathrm{OH})_{2}$ solution; $\mathrm{W}$ is a mass of latex corresponding to $10 \mathrm{ml}$ of acidified serum, and TS is a percentage of total solids in the latex.

\section{RESULTS AND DISCUSSION}

The yield preserved of NR latex or raw latex was irradiated by gamma rays from a Cobalt- 60 source with 10, 20, 30, $40 \mathrm{kGy}$ doses. The vulcanization dose of the raw latex increasing by increasing the irradiation dose as shown in Figure 1. These results confirm the Makuuchi's suggestion [4] that the blending would probably be utilized in the RV raw latex. The tensile strength for the blended raw latex of high tensile strength latex (LA) and low tensile strength latex (LB) is lower than that of LA and higher than that of LB. Generally, the blend of a high quality and low quality RV raw latexes improves the low quality latex and degrades the high quality latex.

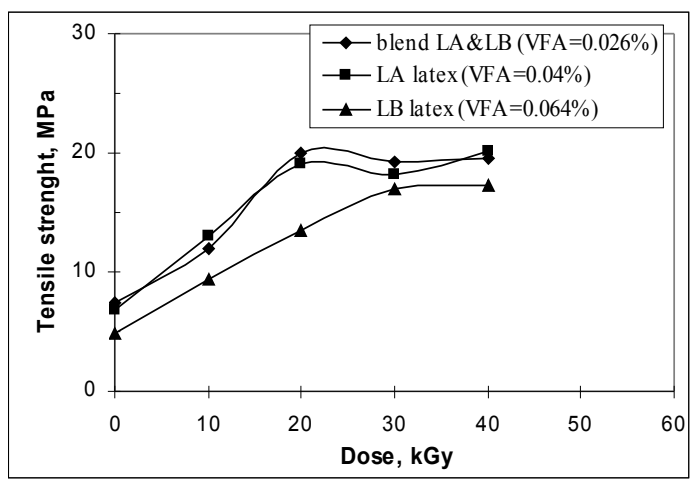

Figure 1. Tensile strength of films from RVNRL by gamma-rays.

The Figure 2 shows that the VFA number when raw latexes is freshly it was slowly decrease by increasing the irradiation dose and arising $0.034 \%$ at maintaing constant. This result indicates that the non-rubbers present in natural rubber latex have no significant effect on crosslinking by radiation. Although, when the raw latex was stored 1 month or 4 month the VFA number increasing.

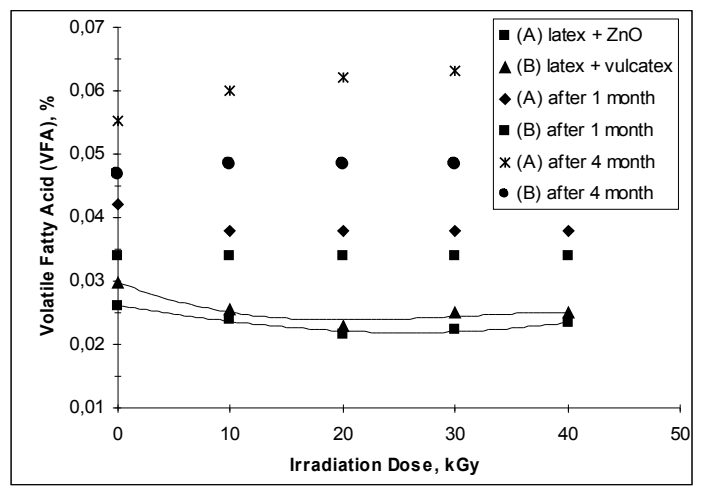

Figure 2. Relation between irradiation dose and VFA number preserved latexes with $\mathrm{ZnO}$ and Vulcatex.

The VFA number increasing by increasing the irradiation dose, to $0.055 \%$ at $0.064 \%$ after irradiation, when the raw latex was preserved with $\mathrm{ZnO}$ and stored for 4 month. But when the raw latex was preserved with vulcatex and stored for 4 month the VFA number was maintaing constant by increasing the irradiation dose. The practice shows that low VFA number showing a higher physical strength of the film, both unvulcanized and vulcanized. Probably the condensation of a large number irregular large aggregates of NR particles can not be expected to form a fine structure of the film, and consequently a low physical strength of the film was obtained. Well prepared concentrated NR latex will be able to form a good film of VR NR latex. Experience showed that concentrated NR latex with VFA number less than $0.02 \%$ will be good for preparing RV NR latex. It the VFA number is much higher than $0.02 \%$, it indicates that the microorganism attack proceed too far.

\section{CONCLUSION}

The blend of a high quality and low quality RV NR latexes improves the low quality latex and 
degrades the high quality latex. Concentrated NR latex with VFA number less than $0.02 \%$ will be good for preparing RV NR latex.

\section{REFERENCES}

1. Gorton, A.D.T. and Pendle, T.D. (1986). The Processability of lattices in relation to their properties, Intern Rubb. Conf., Kuala Lumpur.

2. Gorton, A.D.T. and Pendle, T.D., (1986). Properties and Processability of HA lattices, J. Nat. Rubb. Research, 1, 122.

3. Makuuchi, k. . Progress in Radiation Vulcanization of Natural Rubber Latex through International Cooperation. JAERI-M 89-228, 91-99. Proceedings the First International Symposium on Radiation Vulcanization of Natural Rubber Latex (RVNRL), held at Tokyo, Japan (1989).

4. Makuuchi, k., Yoshii, F., Miura, H., Murakami (1996). K. Proceedings of the second International Symposium on RVNRL, p. 64.

5. Canavel, V. Efeito do antioxidante e do radiosensibilizador na estabilidade do látex de borracha natural vulcanizada com raios gama. Dissertação (Mestrado) - Instituto de Pesquisas Energéticas e Nucleares (1993).

6. Chirinos, H.D.; Guedes, S.M.L. The manufacture of surgical gloves using RVNRL: parameters of the cogulant dipping process. Brazilian J. Chem. Eng., v. 15, n. 04, (1998) p. 33442.

7. ASTM D 1076-79 The analytical methods used to characterize the latex (updated) (1979).
8. ASTM D 1822-L (1979). Dumbbell shaped test pieces methods used to tensile test of natural rubber latex film.

9. Chirinos, H.D.; Yoshii, F. Makuuchi, k. Crosslinking Parameters of Natural Rubber Latex Using Gamma Rays and Electron Beam Radiation. KGK - Kautschuk Gummi Kunststoffe, $\mathrm{n}^{\circ} 10,(2007)$ p 535-41.

10. Chirinos, H.D. Parameters Interactions of Radiation Vulcanized Natural Rubber Latex (RVNRL) Sensitized by n-butyl acrilate. Periódico Tchê Química, V-4, nº 8,(2007) p 21-30.

11. Yanti, S. S. et al. (1996), Application of Radiation Vulcanized Natural Rubber in Indonesia. Proceeding of the Second International Symposium on RVNRL, Kuala Lumpur, Malaysia, 173.

12. Zhu, N.; Wang, C.; Makuuchi, k.; Yoshii, F., Study on Radiation Vulcanization of Natural Rubber Latex. Nuclear Science and Techniques v. 8(1), (1997) p. 51-2.

13. Zin, W, M; Mohid, N; Razali, M. , RVNRL a Potential Material in Latex Dipped Products Manufacturing. Radiation Physics and Chemistry, v. 46(4-6), (1995) p. 1019-23.

14. Duclerc, F. Parra; Martins, C.F.P.; Hugo, D. C. C; Lugão, A. Extractable Proteins from Field Radiation Vulcanized Natural Rubber Latex. Nuclear Instruments and Methods in Physics Research $B$ - Beam Interactions with Materials \& Atoms. 236, (2005) p 508-12. 